\title{
Syndrom NIMBY jako wyzwanie dla jednostek samorządu terytorialnego*
}

\section{Maria Bednarek-Szczepańska, Karolina Dmochowska-Dudek}

\begin{abstract}
STRESZCZENIE
W artykule przedstawiono wybrane zagadnienia problematyki konfliktów typu NIMBY. Są to konflikty wynikające z opozycji społeczności lokalnych wobec lokalizacji, w okolicy ich miejsca zamieszkania, inwestycji, postrzeganych przez nie za uciążliwe. Przedstawiono przestrzenny obraz występowania konfliktów w Polsce (z wyłączeniem dużych i średnich miast), będący wynikiem kwerendy archiwów prasowych (prasy regionalnej i lokalnej) przeprowadzonej dla okresu styczeń 2007 - marzec 2014. Z badań wynika, że najczęstszymi obiektami protestu społeczności lokalnych były inwestycje z zakresu energetyki odnawialnej oraz infrastruktury drogowej. W artykule omówiono również zagadnienia: podstawy prawnej lokalizacji niechcianych inwestycji, etapu rozpoczęcia konfliktów, efektów konfliktów. Na podstawie badań konfliktów lokalnych w 116 gminach okazało się, że nieco więcej było przypadków, że oprotestowywana przez mieszkańców inwestycja ostatecznie nie powstała niż przypadków takich, że powstała. Przedstawiono także różnorodne formy reagowania władz lokalnych na protesty przeciwko kontrowersyjnym inwestycjom, w tym działania skierowanie do mieszkańców czy działania w ramach postępowań prowadzących do lokalizacji inwestycji. Artykuł ten zawiera wyniki badań opublikowanych w 2016 r. w książce z serii Prace Geograficzne, autorstwa M. Bednarek-Szczepańskiej i K. Dmochowskiej-Dudek pt. Syndrom NIMBY na obszarach wiejskich w Polsce. Specyfika i uwarunkowania konfliktów wokót lokalizacji niechcianych inwestycji.
\end{abstract}

\section{Wprowadzenie}

Celem tego opracowania jest przedstawienie zarysu problematyki konfliktów wywołanych tzw. syndromem NIMBY na obszarach wiejskich w Polsce, ze szczególnym uwzględnieniem zagadnień istotnych dla samorządowców. Opracowanie jest w znacznej części syntezą wybranych zagadnień opublikowanych przez autorki w 2016 r. w książce Syndrom NIMBY na obszarach wiejskich w Polsce. Specyfika i uwarunkowania konfliktów wokół lokalizacji niechcianych inwestycji (Prace Geograficzne 255).

Społeczności lokalne przeciwstawiają się powstawaniu w sąsiedztwie swojego miejsca zamieszkania inwestycji, które w ich opinii są uciążliwe i pogarszają jakość życia. Jednocześnie są to według nich obiekty potrzebne ogółowi społeczeństwa, które powinny jednak powstać gdzieś indziej. Opozycja mieszkańców wobec konkretnej lokalizacji inwestycji, przy aprobacie dla danego typu inwestycji ogólnie, to wyróżniki tzw. syndromu NIMBY (z języka angielskiego not in my backyard - „nie na moim podwórku”). Z syndromu NIMBY wynika konflikt typu NIMBY, będący sekwencją wydarzeń, które inicjuje grupa mieszkańców, próbująca przeciwdziałać powstaniu niechcianej inwestycji. Poza protestującymi mieszkańcami i - po drugiej stronie - inwestorem, w konflikt zaangażowane są najczęściej władze lokalne, a także organizacje, część społeczności popierająca powstanie inwestycji itd. 
Protestujący mieszkańcy (nimbyści) nie chcą ponosić kosztów (uciążliwości) funkcjonowania kontrowersyjnej inwestycji, nawet w przypadku, gdy również oni będą z niej korzystać (np. z nowej drogi). Często są zaskakiwani planami inwestycyjnymi w swojej okolicy, czują się pominięci w procesie planowania i mają poczucie krzywdy - zwłaszcza wtedy, gdy nie ma szans na uzyskanie żadnej istotnej rekompensaty.

Problematyka NIMBY jest bardzo popularna w literaturze międzynarodowej. Liczne publikacje poświęcono społecznym protestom przeciwko różnego rodzaju obiektom NIMBY, w tym farmom wiatrowym [m.in. Wolsink 2000, 2006; Bell i in. 2005; van der Horst 2007; Kempton i in. 2005; Pasqualetti 2000; Krohn i Damborg 1999], instalacjom unieszkodliwiania odpadów [Rahardyan i in. 2004; Caplan i in. 2007; Groothuis i Miller 1994], więzieniom [Martin 2000], ośrodkom pomocy dla bezdomnych [Takahashi i Dear 1997], biogazowniom [Upreti 2004], fermom hodowlanym [Mann i Koegl 2003] i wielu innym.

W Polsce tematyka ta nie była dotychczas popularna. W latach 80 . XX wieku geografowie z Polskiej Akademii Nauk poświęcili nieliczne prace temu zjawisku, traktując konflikty jako kolizję w planowaniu przestrzennym pomiędzy konfliktogennymi funkcjami np. przemysłową a mieszkaniową przyrodniczą czy turystyczną - bez uwzględnienia roli człowieka jako kluczowego aktora [Grocholska 1986; Kołodziejski 1982]. Od lat 90. XX wieku, protesty społeczności lokalnych i konflikty wokół lokalizacji inwestycji stały się przedmiotem badań naukowców reprezentujących różne dyscypliny naukowe [np.: Matczak 2000, 2004; Hackiewicz 2011; Michałowska 2008; Łucki i Misiak 2010; Graczyk 2010; Jarosiński i Wójcicki, 2010; Dmochowska-Dudek 2008, 2013; Gorzym-Wilkowski 2012].

\section{Konflikty typu NIMBY w przestrzeni wiejskiej Polski}

Dotychczasowe badania konfliktów wokół lokalizacji niechcianych inwestycji w Polsce najczęściej dotyczyły niewielkich obszarów czy pojedynczych przypadków konfliktów. Nie podejmowano prób zdiagnozowania tych zjawisk w przestrzeni całego kraju. Jest to zadanie bardzo trudne, gdyż występowanie konfliktów nie jest monitorowane przez żadne ogólnokrajowe czy nawet regionalne instytucje, w szczególności nie są na ich temat gromadzone dane statystyczne. Autorki niniejszego tekstu podjęły pierwszą w Polsce próbę przestrzennej diagnozy konfliktów obejmującą obszar całego kraju bez dużych i średnich miast. Do pozyskania informacji o występowaniu konfliktów typu NIMBY wykorzystano kwerendę archiwów prasowych. Kwerendzie poddano 48 tytułów prasy regionalnej i lokalnej (pokrywających swym zasięgiem, możliwie równomiernie, cały kraj), publikowanej w okresie styczeń 2007 - marzec 2014. Szczegółowe informacje na temat tej kwerendy opublikowano we wspomnianej książce, tutaj przytoczone zostaną najważniejsze jej wyniki.

Zidentyfikowano występowanie konfliktów we wszystkich regionach Polski (ryc. 1), przy czym najbardziej znamienne jest ich nagromadzenie w strefach podmiejskich wokół największych miast w kraju. Największa gęstość konfliktów wyrażona ich liczbą na $1000 \mathrm{~km}^{2}$ występowała w sąsiedztwie: Poznania, Warszawy, Trójmiasta, Wrocławia, Opola, Kielc i Rzeszowa, a także w pasie pomiędzy aglomeracjami śląską i krakowską. Ponad $40 \%$ wszyst- 


\section{Ryc. 1. Konflikty NIMBY na obszarach wiejskich i w małych miastach w Polsce w latach 2007-2014}

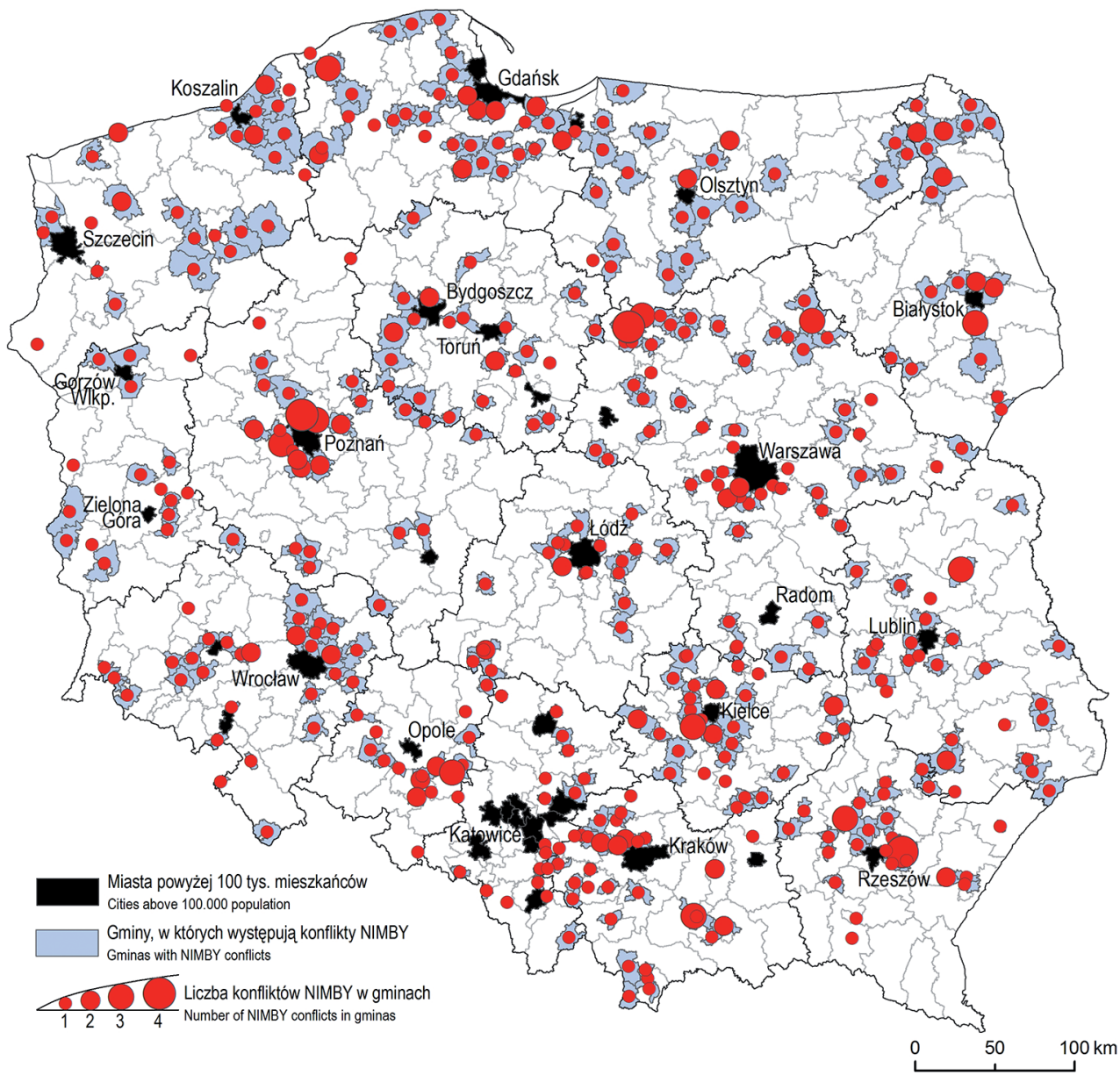

Źródło: M. Bednarek-Szczepańska i K. Dmochowska-Dudek 2016

kich konfliktów (233) skoncentrowane było w odległości do 30 km od dużego miasta (liczącego powyżej 100 tys. mieszkańców), kolejne 40\% w strefie 30-60km, zaś w odległości powyżej 60 km od dużego miasta miało miejsce $20 \%$ zidentyfikowanych konfliktów.

Najczęściej to obiekty infrastruktury technicznej były przedmiotem protestów społeczności lokalnych (ryc. 2), rzadziej obiekty infrastruktury gospodarczej (ryc. 3), a najrzadziej - społecznej. W tym prawie 1/3 wszystkich oprotestowywanych inwestycji, o których znaleziono relację w prasie, były to inwestycje energetyczne. Wśród nich zdecydowaną więk- 


\section{Ryc. 2. Rozmieszczenie obiektów NIMBY z zakresu infrastruktury technicznej według rodza- jów działalności (w nawiązaniu do sekcji PKD)}

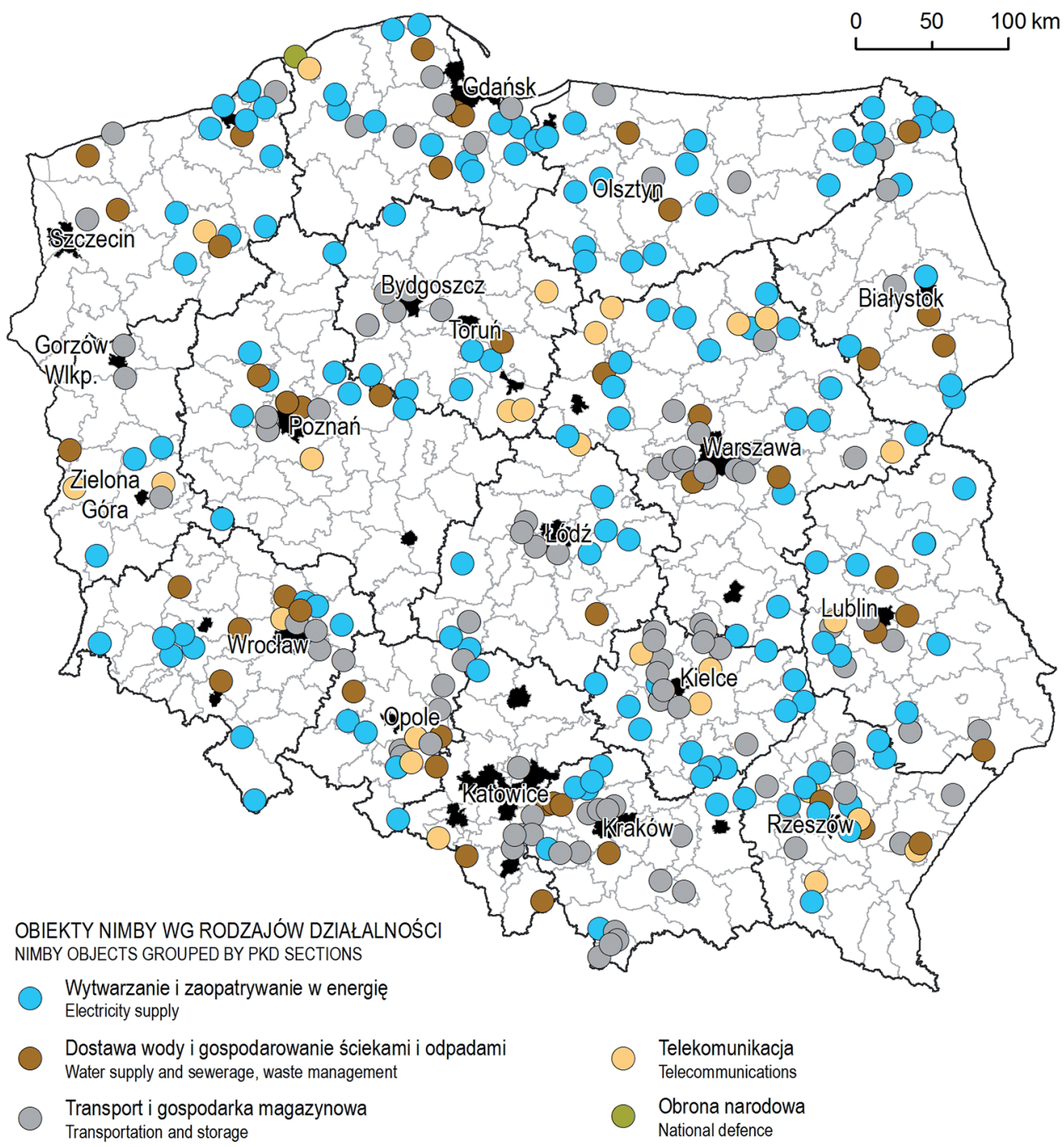

Źródło: M. Bednarek-Szczepańska i K. Dmochowska-Dudek 2016

szość stanowiły obiekty energetyki odnawialnej. Około 20\% wszystkich oprotestowywanych inwestycji (102 przypadki z 499 ogółem) stanowiły farmy wiatrowe, zaś 9\% - biogazownie rolnicze. Jedna czwarta konfliktów dotyczyła infrastruktury transportowej, w tym w zdecydowanej większości budowy lub modernizacji dróg. Około 10\% przypadków były to protesty przeciwko lokalizacji instalacji do unieszkodliwiania odpadów (zakładów utylizacji, 
Ryc. 3. Rozmieszczenie obiektów NIMBY z zakresu infrastruktury gospodarczej według rodzajów działalności (w nawiązaniu do sekcji PKD)

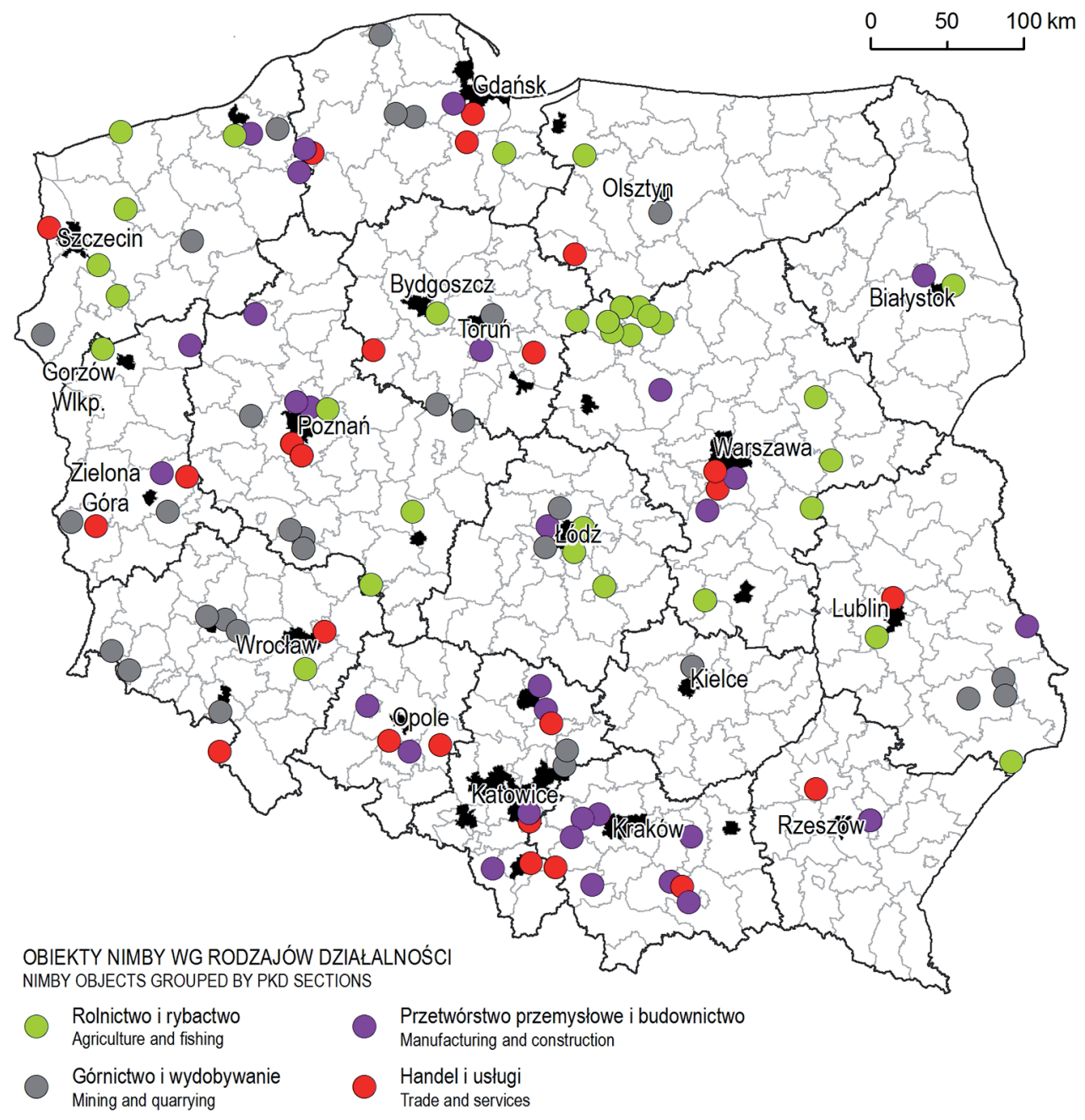

Źródło: M. Bednarek-Szczepańska i K. Dmochowska-Dudek 2016

spalarni, składowisk). Konfliktogennymi inwestycjami okazały się również fermy hodowlane (7\% przypadków). Warto tu zaznaczyć, że łącznie zidentyfikowano aż 41 typów obiektów będących przedmiotem konfliktów (typ jest odpowiednikiem działu w PKD), lecz tylko te kilka z nich występowało często.

Różnorodność przedmiotu konfliktów, mierzona stosunkiem liczby konfliktów do liczby typów oprotestowywanych obiektów, była znacznie wyższa na obszarach podmiejskich 
i w małych miastach niż na obszarach peryferyjnych. Nawiązuje to do zróżnicowania funkcjonalnego tych obszarów.

\section{Konflikty „pod lupą”}

Konflikty typu NIMBY łączy to, że są inicjowane przez społeczność lokalną (a ściślej - jakąś część tej społeczności), która nie zgadza się na lokalizację inwestycji w pobliżu własnych domów, działek, pól itd. Społeczność ta zaczyna podejmować działania mające na celu zablokowanie jej realizacji starając się wywierać wpływ na decyzje podejmowane w sprawie lokalizacji inwestycji. Jak wynika z przeprowadzonych badań ${ }^{1}$, konflikty NIMBY różnią się między sobą pod wieloma względami.

Konflikty możemy podzielić ze względu na lokalizację spornej inwestycji względem miejsca zamieszkania protestujących i ogólny charakter planowanej inwestycji.

1. Konflikty o lokalne inwestycje w gminie:

- publiczne (inwestorem jest gmina),

- prywatne (inwestorem jest podmiot prywatny);

2. Konflikty o lokalne inwestycje w gminie sąsiedniej;

3. Konflikty o inwestycje ponadlokalne.

Lokalizacja i ogólny charakter inwestycji wpływa na to, kto jest decydentem w procesie lokalizowania inwestycji, a więc do kogo skierowane są działania protestujących. Tylko w pierwszych dwóch przypadkach decydentem są władze gminy, w której mieszkają protestujący. Wtedy protestujący starają się wpłynąć na decyzje swoich władz zbierając podpisy pod petycjami, uczestnicząc w sesjach rady, w zebraniach z wójtem itd. Gdy inwestorem jest gmina, to jej władze są jednocześnie stroną konfliktu. Tym niemniej w konfliktach wymienionych w punkcie pierwszym protestujący mają relatywnie największe szanse wywarcia wpływu na postępowania toczące się w sprawie lokalizacji inwestycji. Często władze nie chcą narażać się swoim wyborcom, postępować wbrew woli mieszkańców i rezygnują z niechcianej inwestycji.

Konflikty wymienione w punkcie drugim mają miejsce wtedy, gdy mieszkańcy obawiają się uciążliwości inwestycji lokalizowanej w sąsiedniej gminie, najczęściej gdzieś przy jej granicy. Decydentem są w takiej sytuacji władze tej sąsiedniej gminy i to do nich protestujący kierują swoje działania, zaś władze ich gminy mogą ich tylko wspierać. W ostatnim przypadku mamy do czynienia na ogół z dużymi i skomplikowanymi inwestycjami, o znaczeniu regionalnym lub ogólnokrajowym, o lokalizacji których decydują np. władze województwa czy Generalna Dyrekcja Dróg Krajowych i Autostrad. Wtedy najtrudniej jest niewielkim społecznościom lokalnym zmienić przebieg procesu decyzyjnego, nawet w przypadku zaangażowania władz lokalnych we wspieranie swoich mieszkańców w protestach.

Badania dotyczące konfliktów o inwestycje lokalne w 116 gminach w Polsce wskazały, że zróżnicowana była podstawa lokalizacji inwestycji, którym sprzeciwiali się mieszkańcy.

\footnotetext{
${ }^{1}$ Były to zarówno badania ankietowe przeprowadzone w 116 urzędach gmin w Polsce, jak i pogłębione badania w 9 studiach przypadku (szerzej w: Bednarek-Szczepańska i Dmochowska-Dudek 2016).
} 
Tabela 1. Podstawa lokalizacji spornych inwestycji na podstawie badań konfliktów o inwestycje lokalne w 116 gminach

\begin{tabular}{|l|c|}
\hline \multicolumn{1}{|c|}{ Podstawa lokalizacji spornej inwestycji } & Liczba przypadków \\
\hline Decyzja lokalizacyjna & 54 \\
\hline Istniejący plan miejscowy & 28 \\
\hline Plan miejscowy tworzony pod kątem tej inwestycji & 17 \\
\hline Plan miejscowy zmieniany pod kątem tej inwestycji & 12 \\
\hline Brak danych & 5 \\
\hline
\end{tabular}

Jak pokazano w tabeli 1., najczęściej kontrowersyjne inwestycje miały powstać na podstawie decyzji. Nie jest dobrze, że mogące budzić sprzeciw społeczny inwestycje tak często są lokalizowane na mocy decyzji. W postępowaniach prowadzących do wydania decyzji uwz czy ulicp udział społeczny jest bardzo ograniczony w porównaniu do postępowania planistycznego. Konsultacje społeczne są możliwe tylko na etapie oceny oddziaływania na środowisko. Znaczący był też udział przypadków, w których specjalnie na potrzeby planowanej inwestycji władze lokalne przystępowały do tworzenia nowego planu miejscowego lub zmiany planu istniejącego. W tych wszystkich sytuacjach mieszkańcy byli zaskakiwani zamierzeniami inwestycyjnymi.

Konflikty można podzielić też ze względu na czas ich rozpoczęcia, czyli etap, na którym mieszkańcy dowiadują się o planowanej inwestycji i rozpoczynają działania mające na celu jej zablokowanie. Wyróżniono konflikty rozpoczynające się:

- we wstępnej fazie planowania inwestycji (przed wszczęciem postępowań administracyjnych lub planistycznych);

- na etapie prac nad dokumentami planistycznymi (w przypadku inwestycji lokalizowanych na podstawie planu miejscowego);

- na etapie oceny oddziaływania na środowisko;

- po uzyskaniu decyzji środowiskowej.

Z przeprowadzonych badań wynika, że najczęściej konflikty rozpoczynały się na etapie prac nad dokumentami planistycznymi, a w przypadku inwestycji lokalizowanych na podstawie decyzji o warunkach zabudowy (lub decyzji ulicp) - w trakcie oceny oddziaływania na środowisko. Na tych etapach protestujący mogą realnie wpłynąć na bieg sprawy. Były liczne przypadki konfliktów, gdzie pod wpływem protestujących władze gminy wygaszały postępowanie w sprawie zmiany studium lub planu miejscowego, mającej umożliwić lokalizację niechcianej inwestycji, wydawały negatywne decyzje środowiskowe (nawet mimo pozytywnych uzgodnień organów). Najmniejsze możliwości wpływu społeczności na proces lokalizowania inwestycji są wtedy, gdy wydana jest już decyzja środowiskowa. Choć zdarzały się pojedyncze przypadki, gdy mieszkańcy dowiadywali się o planowanej, uciążliwej dla 
nich inwestycji dopiero na etapie pozwolenia na budowę i w drodze skutecznych odwołań od decyzji udawało im się zablokować realizację inwestycji.

Konflikt o lokalizację inwestycji jest wyzwaniem i ważnym doświadczeniem dla władz lokalnych. Są one zawsze w jakiejś formie zaangażowane w konflikt. Organy gminy są zobowiązane do stosowania przepisów prawa określających zakres i charakter udziału społeczności lokalnej w postępowaniach prowadzących do lokalizacji inwestycji. Z drugiej strony moga poza realizacją ustawowych obowiązków, w różny sposób reagować na zaistniały konflikt w celu jego rozwiązania i zapobieżenia podobnym sytuacjom w przyszłości. We wspomnianym badaniu w 116 gminach w Polsce oraz w studiach przypadku zidentyfikowano szereg działań, które podejmowali wójtowie i rady gmin wobec protestów mieszkańców. Zestawiono je poniżej.

Działania skierowane do mieszkańców:

- organizacja spotkań informacyjnych dla mieszkańców;

- pośredniczenie w negocjacjach pomiędzy mieszkańcami a inwestorem;

- organizacja konsultacji społecznych i referendów lokalnych², w których mieszkańcy mogą się wypowiedzieć na temat planowanej inwestycji;

- powołanie zespołu pracowników do informowania i współpracy z mieszkańcami w sprawach związanych z kontrowersyjną inwestycją;

- podejmowanie przez radę gminy uchwał wyrażających poparcie dla protestujących mieszkańców.

Działania w ramach postępowań prowadzących do lokalizacji inwestycji i w sferze planowania przestrzennego:

- wydawanie inwestorowi odmownych decyzji środowiskowych lub lokalizacyjnych mimo niedostatecznych przesłanek prawnych (lub wbrew pozytywnym uzgodnieniom), kierując się sprzeciwem społecznym;

- stawianie inwestorowi dodatkowych wymogów dla inwestycji, proponowanie zmiany lokalizacji;

- wycofanie się, pod wpływem sprzeciwu mieszkańców, z planowanych lub będących w toku zmian dokumentów planistycznych przygotowywanych pod kątem niechcianej inwestycji;

- przystępowanie do zmian istniejących/uchwalania nowych dokumentów planistycznych w celu uregulowania zasad lokalizacji kontrowersyjnych inwestycji, w tym w celu ograniczenia możliwości lokalizacji inwestycji, którym sprzeciwiali się mieszkańcy (np. ustalenie minimalnej odległości takich inwestycji od zabudowy mieszkalnej, ustalenie ich parametrów technicznych);

- podejmowanie innych uchwał dotyczących lokalizacji określonych inwestycji (m.in. określających stanowisko rady wobec lokalizacji wskazanych typów obiektów, zobo-

\footnotetext{
${ }^{2}$ Należy tu zaznaczyć, że, jak wskazuje orzecznictwo Najwyższego Sądu Administracyjnego, referenda, w których mieszkańcy określają przeznaczenie terenów, nie powinny mieć miejsca i nie mogą być wiążące dla organów gminy. Instytucja referendum nie wpisuje się w obowiązujące procedury ustalania polityki przestrzennej i planowania przestrzennego (OSK 344/14).
} 
Tabela 2. Efekt konfliktu o lokalizację inwestycji na podstawie badania konfliktów lokalnych w 116 gminach

\begin{tabular}{|l|c|}
\hline \multicolumn{1}{|c|}{ Efekt konfliktu } & Liczba przypadków \\
\hline Inwestycja nie powstała & 41 \\
\hline Inwestycja powstała ze zmianami w stosunku do pierwotnego projektu & 11 \\
\hline Inwestycja powstała bez zasadniczych zmian & 20 \\
\hline Konflikt jeszcze nierozstrzygnięty & 44 \\
\hline
\end{tabular}

wiązujących władzę wykonawczą do zamieszczania określonych zapisów w dokumentach planistycznych tworzonych w przyszłości, zobowiązujących władzę wykonawczą do określonego postępowania przy podejmowaniu decyzji administracyjnych na wniosek inwestorów).

Działania skierowane do instytucji zewnętrznych:

- podejmowanie współpracy z innymi gminami, w których miały miejsce podobne protesty;

- zwracanie się o pomoc, interwencję, opinię do polityków i instytucji szczebla regionalnego lub krajowego.

W badaniu dotyczącym konfliktów o inwestycje lokalne w 116 gminach w Polsce uzyskano też informacje, jaki był ich ostateczny efekt, a zatem, czy oprotestowywana przez mieszkańców inwestycja powstała czy nie (tabela 2). Okazało się, że w 35\% przypadków kontrowersyjna inwestycja nie powstała i nie powstanie. W 27\% - inwestycja powstała lub jeszcze nie powstała, ale inwestor uzyskał wszystkie wymagane decyzje. Spośród tych inwestycji, których realizacji protestującym nie udało się zablokować, około 1/3 powstała/miała powstać ze zmianami korzystnymi dla społeczności lokalnej. Polegały one głównie na zmniejszeniu skali inwestycji lub wprowadzeniu dodatkowych elementów ograniczających uciążliwości dla otoczenia. Warto też zwrócić uwagę na duży udział konfliktów nierozstrzygniętych (ponad 1/3 ogółu), w tym w zdecydowanej większości były to konflikty rozpoczęte w latach 2008-2013. Samo badanie prowadzone było w połowie 2015 r. Postępowania w sprawach lokalizacji inwestycji, przeciwko którym protestują mieszkańcy, toczą się często po kilka lat.

\section{Zakończenie}

Obecnie coraz większą wagę przykłada się do partycypacji społecznej. Społeczności lokalne traktowane są jako ważny podmiot, który powinien współdecydować o kierunkach rozwoju swojej miejscowości, gminy i mieć wpływ na kształt przestrzeni, którą zamieszkuje. Pogląd taki jest ogólnie przyjęty i raczej nie jest kwestionowany, choć dyskusje toczą się nad tym, jak ten udział mieszkańców w „konstruowaniu” swojej okolicy ma przebiegać. Dlatego 
tak ważnym i aktualnym problemem są właśnie konflikty o lokalizację inwestycji. Postawy NIMBY, polegające na sprzeciwie wobec inwestycji, są głosem społeczności lokalnych na temat przeznaczenia i zagospodarowania przestrzeni, w której żyją. Konflikty o podłożu NIMBY to zjawiska złożone i mające wiele aspektów: socjologiczny, urbanistyczny, polityczny, etyczny, ekonomiczny itd. W tym opracowaniu przedstawiono jedynie skromny wycinek tej problematyki. Na zakończenie warto podkreślić, że problematyka ta wymaga pogłębionych badań - w tym szczególnie należałoby się przyjrzeć strefom podmiejskim największych miast, zwłaszcza Warszawy. Tu konflikty występują w dużym natężeniu i przy wzrastającej liczbie mieszkańców, wzrastającej intensywności wykorzystania przestrzeni i różnorodności jej funkcji, konflikty te prawdopodobnie będą się nasilać.

\section{Bibliografia}

Bednarek-Szczepańska M., Dmochowska-Dudek K., 2016, Syndrom NIMBY na obszarach wiejskich w Polsce. Specyfika i uwarunkowania konfliktów wokót lokalizacji niechcianych inwestycji, „Prace Geograficzne”, 255, Instytut Geografii i Przestrzennego Zagospodarowania PAN, Warszawa.

Bell D., Gray T., Haggett C., 2005, The 'social gap' in wind farm siting decisions: explanations and policy responses, „Environmental Politics”, 14, 4, s. 460-477.

Caplan A., Grijalva T., Jackson-Smith, D., 2007, Using choice question formats to dermine compensable values: The case of a landfill-siting process, „Ecological Economics”, 60, s. 834-46.

Dmochowska-Dudek K., 2008, Ustugowe obiekty NIMBY w oczach mieszkańców Łodzi, [w:] A. Rochmińska (red.), Theoretical and empirical researches on services during socio-economic changes, "Space-Society-Economy", 8, s. 189-196.

Dmochowska-Dudek K., 2013, Syndrom NIMBY w przestrzeni wielkomiejskiej. Przykład Łodzi, Wydawnictwo Uniwersytetu Łódzkiego, Łódź.

Gorzym-Wilkowski W., 2012, Planowanie przestrzenne a konflikty wokót wydobycia gazu łupkowego, „Barometr Regionalny”, 4, 30, s. 129-137.

Graczyk A., 2010, Społeczne problemy rozwoju energetyki odnawialnej na obszarach wiejskich, [w:] B. Kryk (red.), Zrównoważony rozwój obszarów wiejskich. Wybrane aspekty społeczne, Uniwersytet Szczeciński, Szczecin.

Grocholska J., 1986, Konflikty w planowaniu przestrzennym i próby ich rozwiazywania na przykładzie wybranych obszarów aglomeracji warszawskiej, „Biuletyn Informacyjny”, 53, Instytut Geografii i Przestrzennego Zagospodarowania PAN, Warszawa.

Groothuis P.A., Miller G.,1994, Locating hazardous waste facilities: the influence of NIMBY beliefs, „American Journal of Economics and Sociology", 53, 3, s. 335-347. 
Hackiewicz M., 2011, Społeczne i prawne aspekty konfliktów na tle zagospodarowania przestrzennego na przykładzie budowy obwodnicy Milanówka i Grodziska Mazowieckiego, „MAZOWSZE Studia Regionalne", 6, s. 123-148.

Jarosiński M., Wójcicki A., 2010, Kwestie istotne dla konsultacji społecznych w sprawie podziemnego składowania dwutlenku węgla na terenie Polski, „Przegląd Geologiczny”, 58, s. 482-489.

Kempton W., Firestone J., Lillej J., Rouleau T., Whitaker P., 2005, The offshore wind power debate, views from Cape Cod, "Coastal Management”, 33, s. 119-149.

Krohn S., Damborg S., 1999, On public attitudes to wind power, "Renewable Energy”, 16, s. 954-960.

Mann S., Koegl H., 2003, On the acceptance of animal production in rural communities, „Land Use Policy", 20, s. 243-252.

Martin, R., 2000, Community perceptions about prison construction: why not in my backyard? „Prison Journal”, 80, 3, s. 265-294.

Matczak P., 2000, Protest lokalny w Polsce, "Ruch Prawniczy, Socjologiczny i Ekonomiczny", LXII, 3, s. 151-160.

Matczak P., 2004, Lokalne protesty na tle ochrony środowiska, [w:] P. Buczkowski i P. Matczak (red.), Konflikt nieunikniony. Wspólnoty $i$ władze lokalne wobec konfliktów spowodowanych rozwojem, Wyd. Wyższej Szkoły Bankowej w Poznaniu, Poznań, s. 59-65.

Michałowska E., 2008, Syndrom NIMBY jako przykład samoorganizacji społecznej na poziomie lokalnym, „Studia Regionalne i Lokalne”, 31, 1, s. 60-80.

Pasqualetti M. J., 2000, Morality, space, and the power of wind-energy landscapes, "Geographical Review", 90, 3, s. 381-394.

Rahardyan B., Matsuto T., Kakuta Y., Tanaka N., 2004, Resident's concerns and attitudes towards Solid Waste Management facilities, „Waste Management”, 24, 5, s. 437-451.

Takahashi L. M., Dear M. J., 1997, The changing dynamics of community opposition to human service facilities, „Journal of American Planning Association”, 63, 1, s. 79-93.

Upreti B.R., 2004, Conflict over biomass energy development in the United Kingdom: some observations and lessons from England and Wales, „Energy Policy”, 32, 6, s. 785-800.

Van der Horst D., 2007, NIMBY or not? Exploring the relevance of location and the politics of voiced opinions in renewable energy siting controversies, "Energy Policy”, 35, s. 2705-2714.

Wolsink M., 2000, Wind power and the NIMBY-myth: institutional capacity and the limited significance of public support, „Renewable Energy”, 21, s. 49-64.

Wolsink, M., 2006, Invalid theory impedes our understanding: a critique on the persistence of the language of NIMBY, „Transactions of the Institute of British Geographers”, 31,1, s. 85-91. 


\section{The NIMBY syndrome as a challenge for territorial self-government units}

\section{ABSTRACT}

Selected problems related to NIMBY-type conflicts are presented in this article. These conflicts result from local inhabitants' opposition to location, in the vicinity of their place of living, of investments which they perceive as burdensome. A spatial image of NIMBY-type conflicts occurrence in Poland (excluding medium-size and big cities) is presented as a result of regional and local press query which was carried out for the period 01.2007-03.2014. The study show, that the most frequent objects of inhabitants' protests were investments in renewable energy and road infrastructure. The following issues are also set out in the article: legal basis of unwanted investments' location, stages of beginning of conflicts, effects of conflicts. It turned out, on the basis of the study on local conflicts in 116 communes, that there was slighty more cases of conflicts which ended with abandonment of project than conflicts which ended with project realisation. Different forms of local authorities' response to the protests against controversial investments were identified, including activities directed at inhabitants or activities related to administrative and planning proceedings. This article contains results of research which were published in 2016 in a book of Geographical Studies series, written by M. Bednarek-Szczepańska and K. Dmochowska-Dudek, The NIMBY syndrome in rural areas of Poland. Specificity and determinants of conflicts on the location of unwanted investments.

\footnotetext{
dr Maria Bednarek-Szczepańska, adiunkt w Zakładzie Geografii Wsi i Rozwoju Lokalnego Instytutu Geografii i Przestrzennego Zagospodarowania Polskiej Akademii Nauk; specjalizuje się w geografii wsi, problematyce rozwoju lokalnego i konfliktów wokót lokalizacji inwestycji; kontakt: Instytut Geografii i Przestrzennego Zagospodarowania PAN, ul. Twarda 51/55, Warszawa, e-mail: bednarek@twarda.pan.pl

dr Karolina Dmochowska-Dudek, adiunkt w Katedrze Geografii Regionalnej i Społecznej Wydziatu Nauk Geograficznych Uniwersytetu Łódzkiego; specjalizuje się w geografii społecznej, GIS, problematyce syndromu NIMBY; kontakt: Wydział Nauk Geograficznych Uniwersytetu Łódzkiego, ul. Kopcińskiego 31, 90-131 Łódź, e-mail: karolina.dmochowska@geo.uni.lodz.pl
} 